\title{
Özel amaçlı Türkçe öğrenimine örnek tarihî bir ders kitabının incelenmesi
}

\section{Bayram ÖZBAL ${ }^{2}$}

\begin{abstract}
APA: Özbal, B. (2020). Özel amaçlı Türkçe öğrenimine örnek tarihî bir ders kitabının incelenmesi.
\end{abstract} RumeliDE Dil ve Edebiyat Araştırmaları Dergisi, (20), 1-11. DOI: 10.2900o/rumelide.791066.

\section{$\ddot{\mathbf{O} z}$}

Türkler ve Almanlar arasında 18. yüzyılda başlayan askerî ilişkiler I. Dünya Savaşı'yla doruk noktasına ulaşmıştır. Bu süreçte birçok Alman askerî ülkemiz topraklarında bulunmuştur. Türkçenin konuşulduğu topraklar üzerinde bulunan Alman askerlerinin hem Türk halkı ile iletişim kurabilmelerini hem de meslekleriyle ilgili konuşmaları yürütebilmelerini sağlamak gereklilik haline gelmiştir. Bu amaçla Almanlar için yabancı dil olarak Türkçe öğrenimi ve öğretimine yönelik birçok ders kitabı yazılmıştır. Bu ders kitaplarından birisi olan Wely Bey Bolland’ın yazdığı ve 1917 yılında Almanya'da Wilhelm Violett yayınevi tarafından basılan “Türkisch für Offiziere und Mannschaften” başlıklı eser, bu çalışmanın inceleme konusudur. Nitel araştırma yaklaşımının benimsendiği bu çalışmada veriler doküman incelemesi yoluyla toplanmıştır. Elde edilen veriler içerik analizine tabi tutularak eserin genel yapısı ortaya çıkarılmış ve temalar oluşturulmuştur. Temalar; hedef kitle, eserin amacı, eserin genel yapısı, dil öğretim metodu, konular ve sözlük olmak üzere altı başlıktan oluşmaktadır. Temalar öncelikle betimlenmiş daha sonra örneklendirilmiş ve yorumlanmıştır. Araştırma sonuçları eserin, askerler için özel amaçlı Türkçe öğrenimi için hazırlanan bir konuşma kılavuzu olduğunu, içeriğinin askerlerin hem mesleki hem de sosyal yaşamlarında karşılaşabilecekleri iletişim durumlarına uygun olarak seçildiğini ve günlük konuşma dilini öğretmeyi hedeflediğini ortaya koymaktadır.

Anahtar kelimeler: Özel amaçlı Türkçe öğrenimi, askerler için Türkçe, Almanlar için Türkçe

\section{Analyzing of a historical textbook exemplary Turkish for special purpose}

\begin{abstract}
The military relations between the Turks and Germans started in 18th century, reached its peak with the World War I. In this process, many German soldiers were on the territory of our country. It became necessary to enable German soldiers on the lands where Turkish is spoken to both communicate with the Turkish people and carry out conversations about their profession. For this purpose, many textbooks have been written for the learning and teaching Turkish as a foreign language for Germans. From one of these books, the book titled "Türkisch für Offiziere und Mannschaften" written by Wely Bey Bolland and published by Wilhelm Violett Publishing House in Germany in 1917 is the subject of this study. In the study, in which the qualitative research approach was adopted, the data were obtained using document analysis. The themes were created by analyzing the data obtained from the study through content analysis. The work was examined under six the theme headings such as target audience, purpose of work, general structure of the work, language teaching method, subjects, and dictionary. The themes first were descrpied and then they were exemplified and interpreted. The results of the study indicate that the work is a phrasebook prepared
\end{abstract}

Prof. Dr. Ayten Genç'e katkılarından dolayı teșekkür ederim.

Dr., MEB Göl Anadolu Lisesi (Kastamonu, Türkiye), ozbalbayram@hotmail.com, ORCID ID: oooo-0002-9054-8963 [Makale kayıt tarihi: 03.06.2020-kabul tarihi: 20.09.2020; DOI: 10.29000/rumelide.791066] 
for special-purpose Turkish learning for the soldiers and its content is selected in accordance with the communication situations that the soldiers may encounter in both professional and social life and aims to teach the spoken language.

Keywords: Learning Turkish for special purposes, Turkish for soldiers, Turkish for Germans

\section{Giriş}

Türkler ve Almanlar tarih boyunca birçok alanda iş birliği yapmıştır. 18. yüzyılın ikinci yarısından itibaren de iki millet arasında ilişkiler askerî bir boyut kazanmıştır. III. Selim döneminde Albay Von Goetze, II. Mahmut döneminde ise Yüzbaşı Von Moltke ve Teğmen Von Berg gibi üst düzey askerî yetkililer Osmanlı Devletinin daveti üzerine İstanbul'a gelmiştir (Wallach, 1985: 8-9). II. Abdülhamit döneminde iki ülke arasındaki askerî ilişkiler daha da artmış ve birçok üst düzey askerî yetkili Osmanlı ordusunun yeniden düzenlemesi için İstanbul'a davet edilmiştir (Ortayll, 1983). Bu ilişkilerin sonucunda iki ülke I. Dünya Savaşı’nda kader ortaklığı yapmıştır. İki ülke arasındaki artan bu askerî ilişkiler Almanların Türkçe öğrenme ihtiyacını ortaya çıarmıştır ve bu amaçla da birçok eser yazılmıştır (Goldenthal, 1865; Hindioglu, 1829; Jehlitschka, 1895; Manissadjian, 1893; Muhiddin, 1916; Németh, 1917; Wahrmund, 1869; Weil, 1916; Wied, 1884). Bu eserlerden bir tanesi de Wely Bey Bolland (18861942) tarafından yazılan "Türkisch für Offiziere und Mannschaften" (Subaylar ve Askerler için Türkçe) isimli eserdir. Eserin yazarı hakkında ulaşılan bilgiler şu şekildedir. Topuzkanamış (2019: 587) yaptığı araştırmada Bolland'ın 1862 yllında tüccar Charles Bolland'ın oğlu olarak İstanbul'da dünyaya geldiği, burada Alman okulunda öğrenim gördüğg̈ ve Almanya'da ticaret eğitimi aldığı bilgisine ulaşmıştır. Yazarın ikinci baskısı 1924 yılında yapılan "Kleine deutsche Sprachlehre für Türken: Methode GaspeyOtto-Sauer" isimli eserin iç kapak sayfasında "daha önceden İstanbul'da Galatasaray Lisesi ve Ticaret Lisesi Almanca öğretmeni olduğu şimdi ise Doğu Dilleri bölümünde öğretmen ve Berlin Üniversitesinde öğretim görevlisi” olduğu bilgisine yer verilmiştir (Bolland, 1924). Yazar, İstanbul'da bulunduğu süre zarfında ayrıca Osmanlı Sarayı için tercümanlık da yapmıştır (Topuzkanamış, 2019: 587). Ünver (2013: 190-191) ise yazar hakkında yaptığı araştırmada Bolland'ın Berlin Humboldt Üniversitesinde Doğu Dilleri Enstitüsünde Alman askerlerine Türkçe öğrettiğini, savaş dersi verdiğini, bu hizmetlerinden dolayı 1918 yılında savaşa yardım hizmet nişanı ile onurlandırıldığını ve savaş sonrası Alman üniversitelerinin Doğu Dilleri Enstitülerinde açılan Türkçe ders adlarında "Türkische Grammatik nach Bolland" (Bolland'a göre Türkçe Dil Bilgisi) şeklinde anılmaya başlandığını aktarmaktadır. Herzog (2010: 98) ise 3Bolland'ın, 1887 yllında Berlin'de kurulan Doğu Dilleri Enstitüsünün (Seminar für Orientalische Sprache) 1916-1931 yılları arasında başkanlığını yaptığını ifade etmektedir. Bu bilgilerden hareketle yazarın bir dönem İstanbul'da daha sonra Almanya'da yaşadığı anlaşılmaktadır. Yazarın, yabancı dil öğretimi-öğrenimi ile ilgili diğer eserlerine katalog taramalarından ulaşılmış ve kronolojik sıraya göre aşağıda yer verilmiştir:

1904). Kleine deutsche Sprachlehre für Türken: Methode Gaspey-Otto-Sauer (Türkler için Almanca küçük sarf: Gaspey-Otto-Sauer usulü). Heildelberg: Julius Gross.

(1915). Erstes türkisches Lesebuch für Deutsche (Almanlar için birinci kıraat kitabı). İstanbul: F. Lefler Matbaası. 
(1916). 4Praktisches türkisches Lehrbuch zum Gebrauch im Selbstunterricht und an Lehranstalten (Kendi kendine ve okullarda kullanım için pratik Türkçe Ders Kitabı). Stuttgart: Wilhelm Violett.

(1916). Türkische Schreibschule mit Mustervorlagen: praktisch Anleitung zur Erlernung der Riq'aSchrift (Örneklerle Türkçe yazma öğretimi: Rik’a yazısı öğrenmek için uygulamalı kılavuz). Stuttgart: Wilhelm Violett.

(1919). Zweites türkisches Lesebuch für Deutsche (Türkler için ikinci kıraat kitabı). Stuttgart: Wilhelm Violett.

Söz konusu eserlerden hareketle Wely Bey Bolland’ın özellikle Almanlar için Türkçe öğretimi/öğrenimi alanında eserler verdiği ve Türkçe öğretimine/öğrenimine katkı sağladığı görülmektedir. Yazarın bu çalışmada incelenen "Türkisch für Offiziere und Mannschaften” isimli eseri Grüßhaber’a (2018: 49) göre I. Dünya Savaşı esnasında Almanca askerî komut dilini içeren ilk iki dilli bir kitaptır. Bu çalışmada da amaç, Bolland'ın sözü edilen bu eserini yabancı dil olarak Türkçe öğretimi açısından incelemektir.

\section{Yöntem}

Nitel araştırmalarda araştırmacı verileri düzenler, tasnif eder, sentezler, örüntüler çıkarır ve bu işlemler sonucunda kavramlara ulaşır ve bulguları raporlaştırır (Gürbüz ve Şahin, 2017: 431). Bu çalışma da nitel bir araştırmadır ve çalışmanın veri kaynağı incelenerek veriler toplamış ve analiz edilmiştir.

\section{Veri kaynağı}

Araştırmanın veri kaynă̆ı, Türkisch für Offiziere und Mannschaften isimli eserdir. Eserin iç kapak sayfasında ismi daha detaylı olarak şu şekilde verilmiştir: Türkisch für Offiziere und Mannschaften: Gespräche, Wörtersammlung und Grammatik zum Selbstunterricht; mit einem Anhang: Gespräche mit Verwundeten und Kranken (Subaylar ve Erler İçin Türkçe: Kendi Kendine Öğrenme İçin Konuşma, Kelime Listesi ve Dil Bilgisi; Yarahlar ve Hastalarla Konuşma Bölümü İlaveli). Özel amaçlı Türkçe öğrenimi niteliğini taşıyan ve Alman askerlere Türkçe öğretiminde kullanılan bu kitap, 1917 yılında Almanya’nın Stuttgart şehrinde Wilhelm Violett yayınevi tarafından basılmıştır.

\section{Verilerin toplanması ve analizi}

Araştırmanın verileri, nitel veri toplama yöntemlerinden doküman incelemesi yoluyla toplanmıştır. Doküman incelemesi, araştırılması hedeflenen olgu veya olgular hakkında bilgi içeren yazılı ve görsel materyallerin analizidir (Yıldırım ve Şimşek, 2016: 189). Çalışmada elde edilen verilerin değerlendirilmesinde ise içerik analizi tekniği kullanılmıştır. İçerik analizinde amaç, toplanan verileri açıklayabilecek kavramlara ve ilişkilere ulaşmaktır. Bunun içinde birbirine benzeyen veriler belirli kavramlar ve temalar çerçevesinde bir araya getirilerek yorumlanır (Yıldırım ve Şimşek, 2016: 242). Eser; hedef kitle, eserin amacı, eserin genel yapısı, dil öğretim metodu, konular ve sözlük olmak üzere altı tema altında analiz edilmiştir. Söz konusu temalar betimlenmiş ve veri kaynağından bölümler alınarak örneklendirilmiştir.

\footnotetext{
$4 \quad$ Eserin cevap anahtarı kitapçığı da bulunmaktadır.
} 


\section{Bulgular ve yorumlar}

Eserin hedef kitlesi isminden de anlaşılacağı gibi "Subaylar ve Erler"dir. Bu nedenle belirli bir kitleyi hedef alan bu eserin askerler için özel amaçlı Türkçe öğrenimi için hazırlandığı söylenebilir. Bu bulguyu eserin önsöz bölümünde yer alan Bolland'ın (1917) “[...] başlı̆̆ın da söylediği gibi eser sadece bir konuşma kılavuzu değildir aynı zamanda daha çok kendi kendine öğrenme için bir ders kitabıdır ve görevli olan askerlerimizin Türk silah arkadaşlarıyla sözlü iletişimlerini kolaylaştırmak ve rahat iletişim kurmaları içindir.” ifadesi desteklemektedir. Yazarın bu ifadesinden hareketle eserin hedef kitlesinin askerler olduğu ve amacının Alman askerlerinin Türk askerlerle ve halkıyla iletişim kurmalarına yardımcı olmak üzere hazırlandığı söylenebilir.

Eser, toplam 152 sayfadan oluşmaktadır. Eserin içindekiler sayfasında eserde yer alan bölüm başlıkları şu şekilde sıralanmıştır: "Günlük yaşamda genel konuşma ifadeleri” (s. 1-6), "Özel durumlarda konuşma ifadeleri” (s. 6-18), "İlgili konuşmalar Almanca çevirileriyle” (s, 18-34), "Komutlar” (s. 34-37), "Askerî rütbeler" (s. 37), "Günler ve aylar" (s. 37), "Hayati yevmiyeye ait umumi konuşmalar" (s. 40-51), "Belediye reisi nezdinde" (S, 51-61), "Dil bilgisi bölümü" (s. 89-109), "Ek-yaralılar ve hastalarla konuşma” (s. 142-152). Eserin kurgusunun daha iyi anlaşılması için eser ayrıntılı incelenerek Tablo 1'de eserin genel yapısı ortaya çıkarılmıştır.

\begin{tabular}{lc}
\hline \multicolumn{1}{c}{ Bölümler } & Sayfa Aralığı \\
\hline I. Bölüm: Konuşma & $1-60$ \\
\hline II. Bölüm: Sözlük & $61-88$ \\
\hline III. Bölüm: Dil Bilgisi & $89-141$ \\
\hline Ek & $142-152$ \\
\hline
\end{tabular}

Tablo 1: Eserin genel yapısı

Tablo 1'de görüldüğü gibi eser üç ana bölüme ayrılabilir. Birinci bölüm, konuşma; ikinci bölüm, sözlük; üçüncü bölüm, dil bilgisi bölümüdür. Kitabın sonunda yer alan ek bölümü de ayrı bir bölüm olarak düşünülebilir. Eser, Tablo 1'de çıkarılan genel yapısı itibariyle "konuşma kılavuzu" olarak nitelendirilebilir. Çalışmanın bu bulgusu Genç’in (2012: 255) "bir dile ait kısa dil bilgisi açıklamalarının, konuşma kalıplarının ve sözcüklerin vb. yer aldığı el kitabı” şeklindeki konuşma kılavuzu tanımıyla örtüşmektedir.

Eserin genel yapısından hareketle ilgili bölümlere daha ayrıntılı bakıldığında "Günlük yaşamda kullanılan genel konuşma ifadeleri” bölümünde sayfaların iki sütuna bölündüğü ve sol sütunda yer alan her bir cümlenin numaralandırıldığı görülmüsstür (bkz. Şekil 1). Numaralandırma işlemi, konuşma bölümünün tamamında uygulanmıştır. Yazar, konuşma bölümünün sonunda Osmanlı Türkçesini bilen veya öğrenmek isteyenler için numaralandırılan tüm cümlelerin Osmanlı Türkçesiyle yazılışlarına yer vermiş̧ir (s.s. 40-60). Numaralandırma sistemiyle kullanıcıların herhangi bir numara da yer alan cümlenin veya diyaloğun Osmanlı Türkçesiyle yazımına kolaylıkla erişimi hedeflendiği söylenebilir. Bu uygulama, Osmanlı Türkçesi bilen kullanıcılar için eserin işlevselliğini artıran bir durum olarak da değerlendirilebilir. 


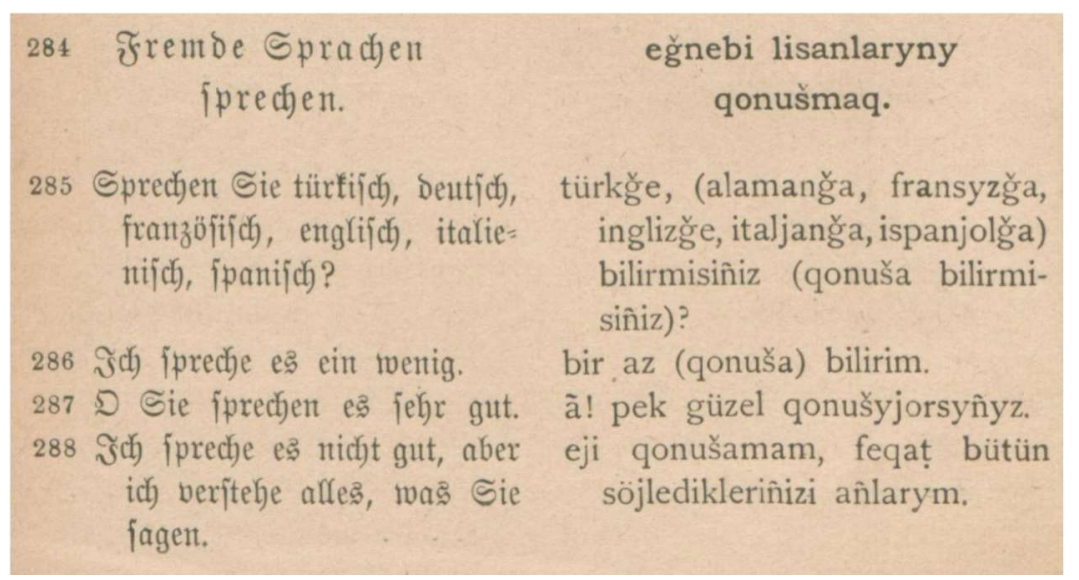

Şekil 1: Konuşma bölümü örneği (Bolland, 1917: 12)

Şekil 1'de görüldüğü gibi konuşma bölümünde sayfaların sol tarafında Almanca cümlelere sağ tarafında ise Latin harfli transkripsiyonlarma yer verilmiştir. Bekar’a (2018: 20) göre transkripsiyon metinleri Türkçe öğrenmek ve öğretmek amacıyla hazırlanmış farklı abece kullanılarak hazırlanmış bir metninin tüm özelliklerini koruyarak başka bir abeceye aktarılmasıdır. Eserde, Almanca cümlelerin Gotik alfabesiyle yazıldığı görülmektedir. Eserde, Alman Doğu Enstitüsü (Deutsche Morgenländische Gesellschaft) tarafından Osmanlı Türkçesi için geliştirilen transkripsiyon sistemi kullanıldığı görülmektedir. Yazarın, diğer eserlerinde de (Bolland, 1924) aynı transkripsiyon sistemini kullanılmıştır. Bu nedenle çalışmanın bu bulgusu Ünver’in (2013) bulgusuyla örtüşmektedir. Eserin, konuşma bölümünde yer alan "Özel durumlarda konuşma ifadeleri" kısmı ise kendi içinde sualler, oturmak, beklemek/intizar etmek, gitmek/yürümek/çımak, gelmek/vasıl olmak, aramak/gidip almak/göndermek/getirtmek/aratmak, koymak/dikmek//yerleştirmek/yatırmak, ecnebi lisanlarıyla konuşma, vakit/zaman/saat/yol sormak, teşekkür etmek ve selam vermek/selamlamak olmak üzere tematik başlıklara ayrılmıştır. Tematik başlıklar altında bu bağlamda kullanılabilecek ilgili cümlelere yer verilmiştir (bkz. Şekil 1).

Konuşma bölümünde yer alan "i̇lgili konuşmalar" kısmı ise belediye reisi nezdinde, askerlerin yerleştirilmesi, bir mağazada, bir çiftlik sahibi ile mükâleme, şehir civarında, bir yerlinin istintakl, harp havadisi, terzide, kunduracı dükkanında, dişçide, berber dükkanında ve ordu/donanma/tayyare olmak üzere temalara ayrılmıştır. Bu temalar altında da ilgili bağlamda diyaloglara yer verildiği görülmektedir (bkz. Şekil 2). 


\section{bir magazada}

baña jarym kilo tere jag̉y, bir kilo șuğuq we jarym kilo țuz weriñiz. - bujuruñuz. - ūn warmy? - hajyr ben ün șatmajorum. bunuñ hepsi ne qadar eder? - tere jağy on ġūruš, șuğuq jedi bučuq ġuruš, jarym kilo țuz da otuz para eder. oradaki paṣdyrma dejilmi? ag̉yrlyğy neqadardyr? fiatyna ne istejorsyñyz? - iki oqqa dyr. we oqqasy bir meǧidije dir. hepsini almaq istejormysyñyz? - jarysyny alajym we size bunuñ ičün ¿ič čerek werejim, išinize gelijormy? - ewet. - ište parañyz.

Şekil 2: Diyalog örneği (Bolland, 1917: 21)

Komutlar bölümünde; esas vaziyette (hazır ol, yerinde say, yerinde rahat), yürürken (kıta/takım/bölük marş), resmi geçitlerde (yerde say, kıta ... marş, yerinde say, ileri marş, adım adım ... marş, kita ... dur) koşarken (koşar adım ... marş marş, kıta ... dur, kıta ... adım,), dönüş komutları (dururken, sağa/sola/geriye dön; yürürken, sağa/sola/ döne, on adım sağa, yarım sola/sağa ... marş, geriye ... dur), tüfekle talim (silah ... omuza, rahat ... dur, dikkat selam ... dur, sağa/sola ... bak), süngü takmak ve yerine itmek (süngü tak, süngü yerine), silaha davranmak (ateş için silah ... hazır, ), ateş komutları (ileride süvari, nişangah dokuz yüz, nişan al, ateş, doldur, yarım solda süvari, nişangah yedi yüz, top ateşi, doldurmaya devam, geri al, silah kapat), hücum (hücum için silah indir, süngü davran ... marş marş, kıta ... dur) başlıkları altında kullanılabilecek komutlara yer verilmiş. Askerî rütbeler bölümde ise nefer, onbaşı, çavuş, baş çavuş muavini gibi askerî rütbelere de yer verildiği görülmektedir.

Eserin konuşma bölümünde yer alan temalar ve bu temalar altında örnek olarak verilen cümlelerden hareketle konuşma öğretiminde düzvarım (doğrudan) yönteminin kullanıldığı söylenebilir. Çünkü bu yöntemde sadece günlük yaşamda kullanılan sözcüklerin ve cümlelerin öğretilmesi (Richards ve Rodgers, 1999: 9), özellikle iletişim kurmak için gerekli sözcüklerin öncelikli olarak öğretilmesi (Sarıgül, 2017: 95) ve konuların gerçek yaşam durumlarından seçilerek (bankada, alışverişte, hava durumu vb.) hedef dilde bu durumlarda uygun konuşuyormuş gibi iletişim kurulması (Larsen-Freeman, 2000: 29) esastır. Tematik başlıklar altında yazarın; teşekkür ederim, bir şey değil, memnun oldum, eyvallah, buyurun(unuz), günaydın, affedersiniz, rica ederim, lütfen, defol(unuz), memnuniyetle, hoş geldin(iniz), görüşmek üzere, afiyet olsun vb. kalıp sözlere de sık sık yer vermesi çalışmanın bu bulgusunu desteklemektedir.

Eserin ikinci bölümünde ise Almanca-Türkçe sözlük yer almaktadır. Sözlük, alfabetik sıraya göre dizinlenmiştir. Sözlükte, Almanca sözcüklerin önce Latin harfleriyle Türkçe transkripsiyonlarına sonra Osmanlı Türkçesiyle yazılışına yer verilmiştir (bkz. Şekil 3). 


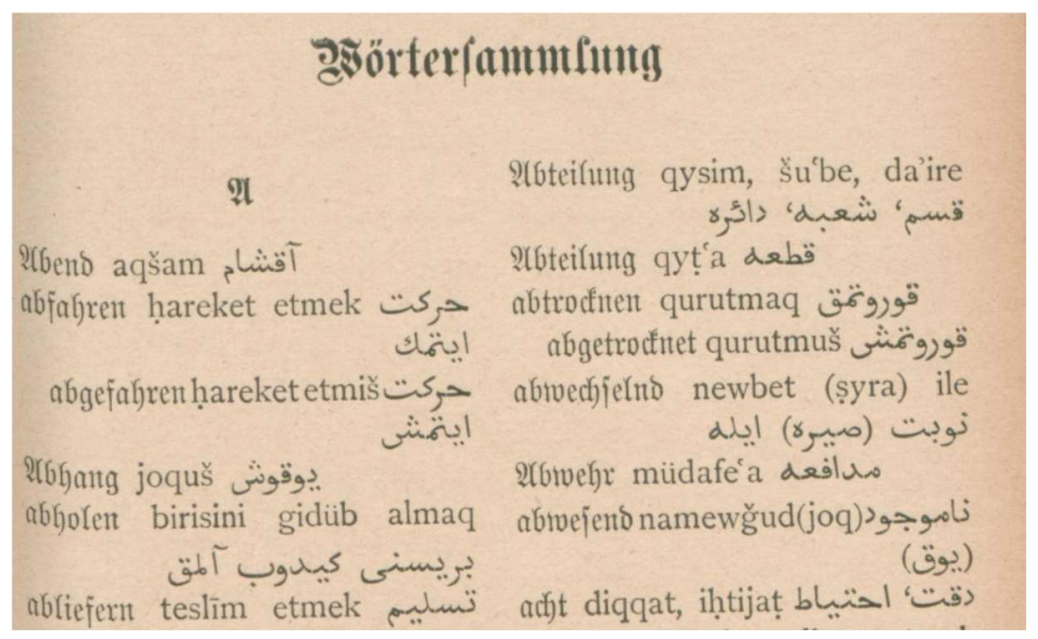

Şekil 3: Sözlük bölümü örneği (Bolland, 1917: 61)

Şekil 3’te verilen örnek sözlük bölümünde görüldüğü gibi bazı madde başı Almanca sözcüklerin farklı anlamlarına yer verilmiştir. Örneğin, Almanca aktion sözcüğünün iş, hareket ve küçük muharebe olmak üzere üç farklı anlamına yer verilmiştir. Sözlükte, bazı sözcüklerin Türkçe anlamlarının eş veya yakın anlamlı kelimelerle de açıklandığı görülmektedir. Örneğin, Almanca absicht sözcüğü fikir, niyet sözcükleriyle açıklanmıştır. Bazı madde başı sözcüklerin anlamlarının açıklanmasından sonra cümle içinde kullanımlarına iç madde şeklinde verildiği de görülmektedir. Örneğin, Almanca alt sözcüğü madde başında eski; ihtiyar şeklinde açıklanmıştır. Daha sonra ilgili sözcük Wie alt sind Sie? (Kaç yaşındasımız?) şeklinde cümle içinde kullanılmıştır. Yazarın, bu uygulamaya önemli gördüğü madde başı sözcüklerde ve kalıp ifadelerde yer verdiği görülmektedir. Ayrıca sözlükte; kıta, küçük muharebe, nöbet, teçhizat, potin, ordu, müfreze, barut, ordugâh, kruvazör, top, tüfek, manga, hücum, askeriye, erkan-ı harp, seri ateş, müttefik, bombardıman etmek, muharebe etmek gibi askerî terimlere yer verilerek askerlerin günlük yaşamda ihtiyaç duyacağı sözcükler öğrenmelerinin ve söz dağarcıklarının zenginleştirilmesinin hedeflendiği söylenebilir.

Eserin üçüncü bölümünde "Dil bilgisi” bölümü yer almaktadır. Dil bilgisi bölümü; giriş, cinsiyet kelimesi, isim, zaman, edatlar ve sayılar başlıkları altında ele alınmıştır. Dil bilgisi bölümde açıklamalar önce Almanca yapılmıştır ancak örneklerde Almanca, Osmanlıca Türkçesi ve Latin harfli transkripsiyon sistemi kullanılmıştır. Yazar, giriş başlığı altında alfabe konusunu ele almıştır. Yazar, konuya Türkçenin sağdan sola doğru yazıldığı, 31 harften oluştuğu, ünlü harflerin neler olduğu ve nasıl okunduğu hakkında bilgilere yer vererek giriş yapmıştır (bkz. Şekil 4). 


\section{(Gramutatisdjer Eeil Einleitunty}

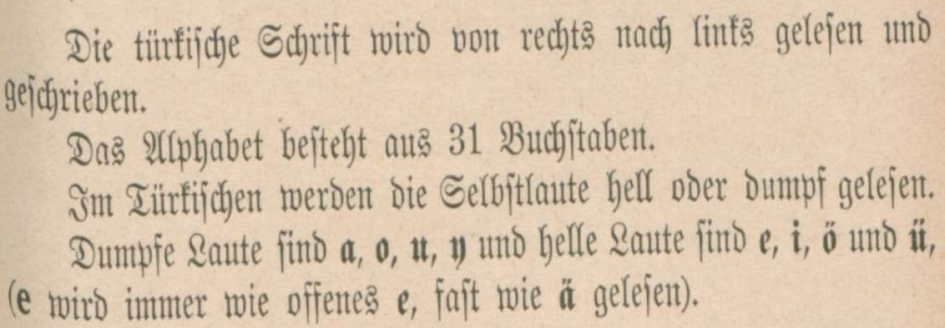

Şekil 4: Dil bilgisi bölümü örneği (Bolland, 1917: 89)

Dil bilgisi bölümü, harflerin öğretilmesiyle devam etmektedir. Harfler, öncelikle Almanca harflerle karşılaştırılarak tek tek tanıtılmış ve sesletimleri hakkında da bilgiler verilmiştir: $ب$ be harfi b gibidir. Kelime sonunda biraz sert okunur (s. 89). Daha sonra da harflerin yazılışları, isimleri, kelime başında/ortasında/sonunda ve transkripsiyonları liste haline getirilerek kullanıcıların bilgisine sunulmuştur (s.s.92-94). Yazar, Türkçede vurgunun son hecede, yumuşak ve kısa olduğunu açıklayarak bu kuralın istisnalarını örneklerle şu şekilde ele almaktadır (s. 95):

Geniş zamanda yardımcı eylemlerin sonunda: im (ym), siñ (syñ), dir (dyr), iz (yz), siñiz (syñyz), dirler (dyrlar): 'askerim (äskerim) ich bin Soldat.

Aynı eklerle yapılan değişik zamanlarda: gelirim (gelīim)

-mi (my, mu) soru edatında vurgu kendinden önceki hecededir ewdémisiñiz Sind Sie zu Hause?

Olumsuzluk eki me (ma) gélmedi er ist nicht gekommen.

Yabancı sözcüklerde vurgu ilk hecededir bérlin Berlin.

Soru kelimelerinde vurgu ilk hecedir nérede wo, né zemän wann.

Dil bilgisini bölümünün ikinci kısmında ise zamanlar başlı̆̆ altında belirli/belirsiz geçmiş, şimdiki, geniş, gelecek zaman ve kipler konularına yer verilmiştir. Edatlar başlığı altında ise için, ile, dolayı ve göre gibi edatlar örnek cümlelerle açıklanmıştır. Sayılar; temel sayılar, sıra sayıları, kesirli sayılar ve üleştirme sayıları olmak üzere dört başlık altında açıklanmıştır. Eserde, dil bilgisi tümdengelim yoluyla öğretilmiştir. Öncelikle kurallar tablo halinde verilmiş daha sonra kurallar örnekler üzerinde gösterilmiştir. Eserde dil bilgisi öğretimi detaylı bir şekilde yapılmamıştır. Yazar, daha çok kullanıcıların ihtiyaç duyacağını düşündüğü konularda kısa bilgilere yer verilmiştir.

Eserin ek kısmında yer alan "Yaralılar ve hastalarla konuşma" bölümde ise sargı mahallinde, hastanede-sabahleyin ve tabip ziyareti temaları altında kullanılabilecek kalıp cümlelere yer verilmiştir (bkz. Şekil 5). 


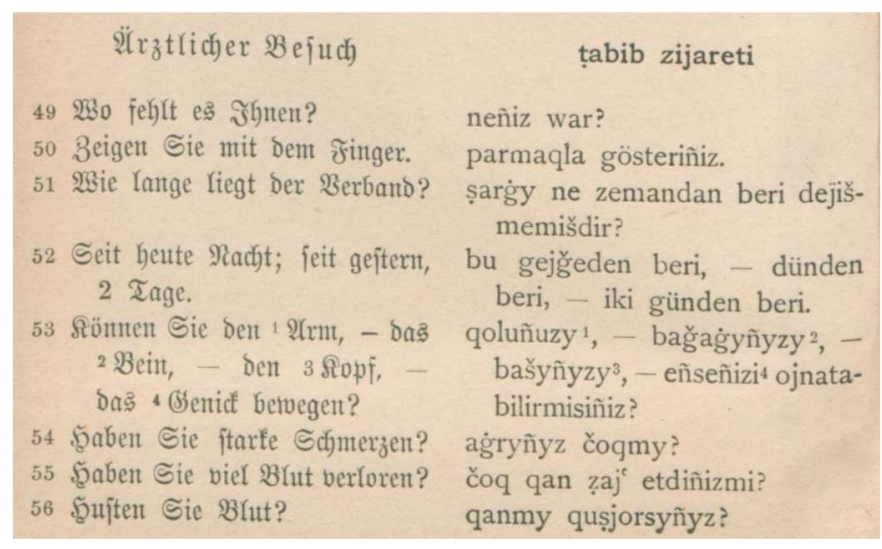

Şekil 5: Ek bölümü örneği (Bolland, 1917: 144)

Eserin ek bölümünde yer alan üç temada toplam 109 cümleye yer verildiği görülmektedir. Numaralandırılarak verilen bu cümlelerin Osmanlı Türkçesiyle yazılı halleri bölüm sonuna eklenmiştir. Ek bölümünde yer alan temalarda sağlık ve askerî çalışanlar arasında iletişim durumlarına yönelik kalıp cümlelere yer verilmiştir.

Eserde yer alan konuşma temalarından, sözlük içeriğinden ve ek bölümünde yer alan diyaloglardan hareketle eserin içeriğinin amacına uygun olarak seçildiğini göstermektedir. Bekar (2018) aynı hedef kitle için Thomas Chabert tarafından yazılan ve 1789 yllında yayımlanmış "Kurze Anleitung zur Erlernung der türkischen Sprache, für Militär Personen. Sammt einer Sammlung von nützlichen Gesprächen, Ausdrücken und Redensarten und einem Handlexikon der gebräuchlichsten Wörter" adlı eseri incelediği çalışmasında eserin askerî personel için hazırlanmış olduğunun belirtildiği ancak içerik olarak yapmış olduğu incelemede askerî personele has olabilecek bir bölüm bulunmadığı ifade etmektedir. Bu bulgu, Grüßhaber'in (2018: 49) çalışmada incelenen eser hakkındaki "Almanca askerî komut dilini içeren ilk iki dilli bir kitap” görüşünü destekler niteliktedir.

\section{Sonuç}

Bu çalışmada Wely Bey Bolland tarafından yazılan ve 1917 yllında Stuttgart'ta Wilhelm Violett yayınevi tarafindan yayımlanan Türkisch für Offiziere und Mannschaften isimli özel amaçlı Türkçe öğrenimi ders kitabı incelenmiş ve şu sonuçlara ulaşılmıştır:

Eser, aslında yazıldığı dönemin Türk-Alman ilişkilerini belgeleyen ve yansıtan tarihî bir eserdir.

Eser, Alman askerlerinin mesleki ve sosyal yaşamlarında iletişim kurmalarını kolaylaştırmak amacıyla yazıldığı için özel amaçlı bir ders kitabı niteliğini taşımaktadır.

Eserde yer alan konuşma temaları, sözlük ve diyaloglar Türkiye'de yaşayan Alman askerlerinin ihtiyaçları göz önünde bulundurularak seçilmiş ve hazırlanmıştır.

$\mathrm{Bu}$ eser, Osmanlı topraklarında bulunan Alman askerlerinin kendi kendine Türkçe öğrenmelerine yardımcı bir konuşma kılavuzu niteliği taşımaktadır.

Konuşma temaları Alman askerlerin hem mesleki (askerlerin yerleştirilmesi, bir çiftlik sahibi ile mükaleme, şehir civarında, bir yerlinin istintakı, harp havadisi) hem de günlük yaşamlarında (terzide, 
dişçide, ayakkabıcıda, berber dükkanında vb.) karşılaşabilecekleri olası iletişim durumları göz önünde bulundurularak hazırlanmıştır. Bu durum, eserin günlük konuşma dilini öğretmeyi hedeflediğini göstermektedir.

Belli bir meslek grubunun sosyal ve mesleki yaşamlarında iletişim kurmalarını sağlama amacı güden bu eserin konuşma öğretiminde düz varım ve dil bilgisi öğretiminde de dil bilgisi-çeviri yöntemlerinden yararlanıldığı dolayısıyla karma bir yönteme dayandırıldığı söylenebilir.

Eserde, Alman askerlerinin Türkçeyi daha kolay okumaları, telaffuz etmeleri ve de daha hızlı öğrenmeleri amaciyla hedef kitlenin kullandığı Latin harfli transkripsiyon sisteminden de yararlanılmıştır.

Eserde yer alan her bir cümlenin Osmanlı Türkçesinde karşıllğının verilmesi ve Latin harflerinin de kullanılması amaca yönelik ve işlevsel bir yaklaşımdır.

Eserin sözlük bölümünde yer alan askerî terimler ve yazıldığı dönemin söz varlığına katkı sağlamakla birlikte günümüzde kullanımı azalmış sözcükler açısından dikkate değer bir eserdir.

Eserin sözlük bölümünde yer alan askerî terimler ve günümüzde kullanımı azalmış sözcükler, yazıldığı dönemin söz varlığına katkı sağlaması açısından önemlidir.

\section{Kaynakça}

Bekar, B. (2018). 1789 yılında askerî personel için yazılmış Almanca-Türkçe transkripsiyon metni. RumeliDE Dil ve Edebiyat Araştırmalar Dergisi, 12, 19-34. doi:10.2900o/rumelide.472750

Bolland, W. B. (1917). Türkisch für Offiziere und Mannschaften. Stuttgart: Wilhelm Violet Verlag.

Bolland, W. B. (1924). Kleine deutsche Sprachlehre für Türken: Methode Gaspey-Otto-Sauer (2. bs.). Heildelberg: Julius Groos Verlag.

Genç, A. (2012). Eğitim sözlüğü (2. bs.). Ankara: Hacettepe.

Goldenthal, J. (1865). Ausführliches Lehrbuch der türkischen Sprache. Wien: Staatsdruckerei.

Grüßhaber, G. (2018). The "German Spirit" in the Ottoman and Turkish army, 1908-1938. Oldenbourg: De Gruyter.

Gürbüz, S. ve Şahin, F. (2017). Sosyal bilimlerde araştırma yöntemleri (4. bs.). Ankara: Seçkin.

Herzog, C. (2010). Almanca konuşulan ülkelerde türkiyat ve şarkiyat çalışmalarının gelişimi üzerine Notlar (Çev. Faruk Yaslıçimen). Türkiyat Araştırmaları Literatür Dergisi, 8(15), 77-148.

Hindioglu, A. (1829). Theoretisch-praktische türkische Sprachlehre für Deutsche. Wien: Anton Edler von Schmid.

Jehlitschka, H. (1895). Türkische Konversations-Grammatik. Heildelberg: Julius Groos.

Larsen-Freeman, D. (2000). Techniques and principles in language teaching (2. bs.). Çin: Oxford University Press.

Manissadjian, J. J. (1893). Lehrbuch der modernen osmanischen Sprache. Stuttgart\&Berlin: W. Spemann.

Muhiddin, A. (1916). Türkische Schönschreibhefte. Leipzig: Harrassowitz.

Németh, G. (1917). Türkische-deutsches Gesprächsbuch. Berlin: G. J. Göschen.

Ortaylı, İ. (1983). Osmanl İmparatorluğunda Alman nüfuzu. İstanbul: Kaynak. 
Richards, J. C. ve Rodgers, T. S. (1999). Appeoaches and methods in language teaching (15. bs.). Cambridge: Cambride University Press.

Sarıgül, E. (2017). Yabancı dil öğretiminde sözcük öğrenimi ve öğretimi sürecine genel bir bakış. The Journal of Academic Social Science Studies, Spring I(54), 91-104.

Topuzkanamış, E. (2019). Teaching Turkish to Germans in 1910s in Istanbul and Berlin: Bolland's book türkisches lesebuch für deutsche. History of Education and Children's Literature, 14(2), 585602.

Ünver, S.. (2013). Alman askerlerine Türkçeyi öğretme ve Türkiye'yi tanıtma amacıyla yazılan bir kitabın incelenmesi. Milli Folklor, 25(100), 189-201.

Wahrmund, A. (1869). Praktische Handbuch der osmanisch-tuerkischen Sprache (1. bs.). Giessen: J. Ricker'sche Buchhandlung.

Wallach, J. L. (1985). Bir askeri yardımm anatomisi. Türkiye'de Prusya-Alman askeri heyetleri 18351919 (çev. Fahri Çeliker). Ankara: Genel Kurmay Basımevi.

Weil, W. (1916). Türkisches Lehrbuch: enthaltend Grammatik, Konversationsübungen, Lesebuch und Wortlisten. Frankfurt: H. Keller.

Wied, K. (1884). Türkischer Dolmetscher. Leipzig: Otto Wigand.

Yıldırım, A. ve Şimşek, H. (2016). Sosyal bilimlerde nitel araştırma yöntemleri (10. bs.). Ankara: Seçkin. 